\title{
An Exploratory Study On The Possibility Of Replacing Tawarruq Based Islamic Banking Products Using Other Alternatives
}

\author{
Zaki Ahmad $^{1}$ \\ Faathih Zahir ${ }^{1}$ \\ Ahmed Mohamud Usman ${ }^{1}$ \\ Aishath Muneeza ${ }^{1}$ \\ Zakariya Mustapha ${ }^{2}$ \\ ${ }^{1}$ International Centre for Education in Islamic Finance \\ (INCEIF), Malaysia \\ ${ }^{2}$ University Malaya, Malaysia
}

\begin{abstract}
Tawarruq which is also known as commodity Murabahah in Islamic banking is widely practiced in Malaysia to structure different types of Islamic banking products. The widespread use of tawarruq has made Islamic banks to be re-named as "tawarruq banks" and some even call tawarruq as the "magic lamp" of the industry. Shariah scholars have criticised this frequent usage of tawarruq in Islamic banking industry of Malaysia, while the practitioners have replied by saying that if tawarruq is a shariah approved concept, then what is wrong with the usage of it? However, from the shariah perspective, the issue here is not about the shariah compliance of tawarruq transactions per se. It is about the shariah limitations imposed by the scholars on the use of it. This simply means that there is a reservation made by shariah scholars in allowing the usage of tawarruq contract in Islamic finance as tawarruq is a contract allowed to be used when one has to choose between a conventional loan and tawarruq. The purpose of this research is thus to show the alternative Islamic commercial contracts that could be used to structure Islamic banking products that have been structured in the market using tawarruq. It is anticipated that the outcome of this research will assist Islamic banking industry to understand why and how they can move away from tawarruq.
\end{abstract}

Keywords: Alternative model of Tawarruq; Ijarah; Islamic Finance; Salam; Tawarruq

Received: 15 May 2020

ISSN 2056-757X

Revised: 25 May 2020

Accepted: 3 June 2020

https://doi.org/10.18646/2056.72.20-011 


\section{Introduction}

At the end of the second quarter of 2017, Islamic Financial Services Board (IFSB) reports Tawarruq as the second most widely used financing product globally at nearly twenty two percent (IFSB, 2017). Even in Malaysia, Bank Negara statistics reveals that more than fifty seven percent of total financing by Islamic finance institutions constitutes of Tawarruq based financing (Bank Negara Malaysia, 2018). Considering the use of Tawarruq commercially in the banking sector started less than two decades ago in Saudi Arabia, the increase of its use worldwide is remarkable.

The Accounting and Auditing Organization for Islamic Financial Institutions (AAOIFI) defined Tawarruq as the process of purchasing a commodity for a deferred price determined through a musawamah (bargaining) transaction or murabaha (markup sale) transaction and selling it to a third party for a spot price in order to obtain cash (AAOIFI, 2010). Unlike the other Islamic finance contracts which are used for sale, lease or investing in physical assets with the intention of owning or generating usufruct from it, Tawarruq is a Shariah compliant method of obtaining liquidity. According to Dusuki (2010), the intention of the buyer of the asset in a Tawarruq transaction is not in utilizing the asset or gaining benefit from it, but to obtain liquidity.

The malleability of Tawarruq to be used in various products, transactions and trade arrangements has made it the 'magic lamp' of the Islamic banking sector. AAOIFI Shariah Standard 30, Paragraph 5/1, 2008, states that Tawarruq should only be used as a contract of last resort when an institution faces liquidity shortage that may affect its sustainability. However, we see in the market that it is the preferred contract of choice not just for working capital requirements, but even for asset financing, trade financing, fixed deposits, sukuk financing, risk management, hedging and even Savings Accounts. Unwittingly, Tawarruq has become the solution to every roadblock to product innovation, development and compliance.

Tawarruq has been able to break barriers and help Islamic financial institutions to penetrate into the market and remain competitive with its conventional counterpart. However, the juristic and economic controversies surrounding this contract cannot be shunned as a matter of opinion. We have come a long way from the classical use of Tawarruq and it has raised more than a few concerns in its contemporary commercial use. Classical Tawarruq was permissible in Islam as a means to meet cash requirements. A person (mustawariq) who needed money purchases a good at a higher price for deferred payments and selling it at a lower price for spot payment. The OIC Fiqh Academy deemed Tawarruq in principle in its classical form was permissible (Mohamad and Ab Rahman, 2014). So was the view of the other scholars too. However, when commercial use of Tawarruq by Islamic financial Institutions began, the process got more organized. Prominent scholars, such as Ibn Qayyim, are strongly against its practice and consider it as fraud against Allah and shariah. According to Obaidullah (2005), Tawarruq (organized) is a prior-arrangement between parties which violates a critical condition for its validity and permissibility. There is a high probability of the financial institution, client and vendors, entering into a prior agreement to the purchase and sale of the commodity.

International Journal of Management and Applied Research, 2020, Vol. 7, No. 2 
From a macroeconomic view, scholars argued that the impacts of harm (mafasid) of Tawarruq outweigh its economic benefits (masalih). And so, such an instrument cannot be justifiably classified as Shariah compliant. Siddiqi (2007) argued that the debt created by a Tawarruq transaction is invariably larger than the cash it transfers to the client and the IFI. Furthermore, the papers resulting from the Tawarruq transaction are subject to repeat financial and speculative transactions where its link with the real assets which they were associated with in the first place are severed. The transaction is then easily moved from the asset market to the money (debt) market where the underlying equilibrating mechanisms are no longer linked the real market.

The objective of this research is thus to examine the controversies revolved around tawarruq and to discuss alternative Islamic commercial contracts to tawarruq in modern Islamic banking, namely home financing, credit card, and fixed deposit. Therefore, this paper will examine the commercial application of Tawarruq used in Malaysia together with the conflicting juristic views of the respective Shariah councils that allow or prohibit the use of the product. Additionally, the paper analyzes some of the macroeconomic views put forth by scholars who claim the product to create more imperfection (fasad) than authenticity (salah). The issue at hand is that the economic implication of Tawarruq, when scrutinized, is more damaging than helpful and the considerations of allowing such a product should be revisited.

\section{Literature Review}

Before Tawarruq gained its popularity in Malaysia, the contract of Bai 'Inah was used to obtain liquidity despite an even more controversial dispute over its permissibility. Maliki and Hanbali jurists considered the contract of 'inah impermissible based on the motive of the parties to be illegal because it constituted a 'hiyal' to obtain a loan with interest (Nursyamsiyah and Kayadibi, 2012). On the other hand, Bank Negara Malaysia (2013) declared Bai' Inah arrangement to be a valid contract in Shariah because it includes two separately and independently executed contracts with no relation to each other. Yet still, some jurists insisted that both the contracts of inah and Tawarruq were similar in nature and their objective, and should be prohibited as products used in Islamic finance. Classical Hanbali Scholars such as Ibn Taymiyyah and Ibn al-Qayyim believe Tawarruq and Inah to be of a forced sale and such an exploitative nature is prohibited in Islam (Ahmed et al., 2017). However, the majority view the contract of Tawarruq to be more favourable over 'inah. Dusuki (2007) writes a majority of the past jurists as well as some of the contemporary jurist's view Tawarruq as more favourable than 'inah. This is because despite the similarities in objective there are clear distinctions in its operation. In reference to Global Islamic Finance Report (GIFR):

"Although Tawarruq shares the same objective as inah as both are meant for extending cash, the former is technically distinguishable from 'inah. Under 'inah, assets bought are resold to the original seller, whereas in Tawarruq the assets are sold to a third party. "Inah is a buy-back arrangement, whilst in Tawarruq the mustawriq is free to sell the assets acquired to anybody for cash" (Global Islamic Finance Report, 2016, p.10).

International Journal of Management and Applied Research, 2020, Vol. 7, No. 2 
Tawarruq was gaining popularity in financial institutions of countries where 'inah was allowed and more prominent before and also countries where 'inah was prohibited. In part, it seemed that it was a necessary product to remain competitive in the market with the conventional institutions as financing is the core business of banks. Bouheraoua (2013) posits that Tawarruq gives the banks its driving force which is liquidity and will continue to use Tawarruq because it guarantees depositors will keep on doing business with them. Tawarruq based financing would help fulfil needs for personal consumption and business capital.

Tawarruq is not a new concept to Islam. However, some jurists accept the contemporary model of organized Tawarruq while others have strong reservations. As Mohamad and Ab Rahman (2014) pointed out, the structure of organized Tawarruq is prohibited by most of the international fiqh bodies and shariah scholars where it is deemed fictitious and considered as hilah for riba. Therefore, it seems necessary to evaluate both the classical and organized models of Tawarruq to understand this position by the jurists and fiqh bodies.

\subsection{Classical Tawarruq (Tawarruq al-fiqhi)}

Classical Tawarruq has been considered as the purer form of Tawarruq in which the person who buys the commodity from a seller on deferred term has the commodity in his possession and he has the choice either to keep it or to sell it in the future (Ahmad et al., 2017).

While there are no explicit texts or expression on the dealings on the practice of Tawarruq in the quran or hadith of the prophet (pbuh), the earliest documented citation can be found in the post-prophetic early Islamic era. The first reference to Tawarruq is traced back to Caliph Ali bin Abu Taleb who said he that would not abandon hajj even if he had to do it through Tawarruq (Ahmed and Aleshaikh, 2014). For some jurists, this saying resonated with its permissibility as the caliph would not have conferred to go for hajj using money from a forbidden sale.

Though the majority juristic opinions on classical Tawarruq are in favour of allowing it, there are a few jurists that ruled against it. Prominent Hanbali school of thought jurists Ibn Taymiyyah and Ibn al-Qayyim forbade Tawarruq even in its classical form, citing that the persons' intention during a Tawarruq transaction is neither to benefit nor to trade in commodities but to borrow money (Ahmed and Aleshaikh, 2014). However, the majority of later scholars of Hanbali school opined classical Tawarruq to be permissible. Contemporary Fiqh academies such as OIC Fiqh Academy also ruled that classical Tawarruq is permissible (Mohamad and Ab Rahman, 2014). Additionally, the Islamic Fiqh council of Muslim World League also declared the classical Tawarruq permissible (GIFR, 2016).

In terms of the contractual relation, there are three different parties: the seller (creditor), the buyer (mustawriq) who is looking for liquidity, and the third party who purchases the commodity from the mustawriq. The purpose of the second sale is to get the cash. Note that in this transaction there are two separate sales without any prearrangement between the parties involved. Classical Tawarruq in this sense is basic, individual and un-arranged (Ahmed and Aleshaikh, 2014, p.282).

International Journal of Management and Applied Research, 2020, Vol. 7, No. 2 


\subsection{Organised Tawarruq (Tawarruq al-munazzam)}

The commercial application of Tawarruq is more complex compared to the classical form of Tawarruq. The purchase and sale transactions are carried out simultaneously with no risks being borne by the bank (GIFR, 2016). The transactions are mostly conducted through a commodity platform which deals in commodities such crude palm oil and iron. The customer does not have any control over which commodity to purchase and later appoints the bank as his agent to sell the commodity purchased by the bank to any third party and forward the proceeds to him (Ahmad et al., 2017).

Despite the similarities in the objectives of both classical and organized Tawarruq which is to obtain financing or liquidity through it, there are a few identified differences between them. The Global Islamic Finance Report (GIFR) 2016 identified three differences between them based on the delivery of the commodity, proceeds of the sale and the pre-arrangement. In organized Tawarruq, the customer does not usually take the possession of the commodity and is not involved in its sale. In terms of the proceeds, in organized Tawarruq, the customer receives the proceeds from the financier who is also the original seller who he is already indebted to. Also, the report highlighted the strong possibility of a pre-arranged agreement between the seller of the commodity and the end buyer in an organized Tawarruq transaction (GIFR, 2016). The table 1 below illustrates the modern juristic views on organized tawarruq.

Table 1: Modern juristic views on Organized Tawarruq

\begin{tabular}{|c|c|}
\hline Jurist & Ruling \\
\hline $\begin{array}{l}\text { OIC Fiqh } \\
\text { Academy }\end{array}$ & Ruled both organised and reversed Tawarruq are impermissible in 2009. \\
\hline AAOIFI & $\begin{array}{l}\text { The Accounting and Auditing Organization of Islamic Financial } \\
\text { Institutions (AAOIFI) approved the use of organized Tawarruq in } 2006 \\
\text { subject to strict fulfilment of the requirements relating to the commodity } \\
\text { and the agency relationship under the (Shariah standard } 30 \text { Article } 4 / 5- \\
\text { The commodity, Article } 4 / 7 \text { to } 4 / 10 \text { - Agency Issues) }\end{array}$ \\
\hline SAC of & $\begin{array}{l}\text { The Shariah Advisory Council (SAC) of Bank Negara Malaysia Tawarruq } \\
\text { (Commodity Murabahah) concept permissible in } 2005 \text {. }\end{array}$ \\
\hline BNM & $\begin{array}{l}\text { It is widely used by Islamic banks in Malaysia in deposit products, } \\
\text { financing, liquidity management and risk management. }\end{array}$ \\
\hline
\end{tabular}

Source: Global Islamic Finance Report (2016, pp. 305-308)

With the adaptation of the resolutions of AAOIFI Shariah Standard 30 and SAC Fatwa declaring Tawarruq as permissible subject to restrictions, the use of Tawarruq by Islamic banks globally has increased significantly. Apart from Bahrain where Tawarruq has been explicitly prohibited, the majority of GCC countries offer financing based on Tawarruq. Hassan (2012) writes that Tawarruq has been gaining popularity in Saudi Arabia, UAE and other GCC countries. Al-Jarhi (2013) estimated that eighty percent of financing products to be based on Tawarruq in Saudi Arabia and fifty percent in UAE. National Commercial Bank of Saudi Arabia introduced a financing product called "Taysir" under the concept of Tawarruq and Abu Dhabi Islamic Bank came up with a product named "Al Khair" for personal financing (Ahmed et al, 2017).

International Journal of Management and Applied Research, 2020, Vol. 7, No. 2 
In Kuwait, the central bank has designed a monetary operation based on Tawarruq to manage the liquidity of its banking system (IMF WP/07/175, 2007). In Malaysia alone, Bank Negara statistics show that fifty seven percent of Islamic financing is issued under the concept of Murabaha, which includes Tawarruq (Bank Negara Malaysia, 2018, 1.32.3).

With the sharp increase in use of Tawarruq in the Islamic banking industry, so has the debate on its permissibility and economic implications. While some juristic opinions have favoured the use of it, prominent Islamic economists have criticised them for being less informed. Siddiqi (2007) argues that the juristic discussions (on Tawarruq) have so far been primarily focused only on the contractual aspects and an important aspect of public policy and financial transactions which is the masalih-mafasid calculus has been ignored. Further he criticised the AAOIFI standards on being oblivious of this essential dimension and largely focused on public interest only (Siddiqi, 2007).

This view is also supported by Dusuki (2010) that the widespread use of Tawarruq increases proliferation of debt and embodies many risks and harmful effects. Mirakhor (2004) claimed that the proliferation of debt using such debt-based instruments increases inequality and redistributes wealth in favour of suppliers of finance irrespective of actual productivity of the supplied finance. Noting the importance of conducting a harm-benefit evaluation of products before offering them in the market, Siddiqi (2007) laid down the worrisome harmful effects (mafasid) of Tawarruq being used in Islamic banking. Whilst equating it to the exchange of money now for more money in the future -- like that of a conventional loan --- he postulated that among the many effects of products of Tawarruq, it leads to creation of exponential debt and its proliferation through speculation. He explained further that by increasing the debtbased products we would be moving to a debt-based economy like that of the conventional system and the tendency of the money supply being linked with debt is to move towards inflationary expansion and instability in the economy. Finally, he boldly theorized that such a product would eventually lead to the problems of the conventional finance system that the Islamic finance system hoped to resolve and avoid, which is the unequal distribution of wealth and inefficient allocation of resources.

According to Al-Jarhi (2015, p. 23), "the prevalence of institutional (organized) Tawarruq has serious implications for the treatment of debt resulting from Islamic commodity finance. In addition, it has even more serious implications for the whole Islamic finance industry." Siddiqi (2007) criticised the permissibility of the sale of debt-obligations in Malaysia, and Gulf countries who permitted its sale as a minority of a larger pack of securities, claimed that this development was welcomed only because it took them back to familiar grounds under conventional finance. Pondering on the same, Dusuki (2010) expanded on this view that though Shariah does not prohibit debt as an individual transaction, a macro perspective on the role of debt in our society today accentuates the harm it can cause.

In addition to concerns of Islamic economists, some opposing juristic concerns are also worth contemplating. Some jurists who opposed Tawarruq took issue with certain

International Journal of Management and Applied Research, 2020, Vol. 7, No. 2 
aspects of the operation of organized Tawarruq, namely; the commodities, delivery and agency that contradict the principles of Shariah. In relation to commodities, Shayk 'Ali al-Quradaghi narrated a Tawarruq transaction that was brokered in the international commodity market using junk, defective aluminium from Russia that had been in storage for ten years, as the underlying commodity (Al-Quradaghi, 2008, Dusuki, 2010). This begs the question of the authenticity of the purpose of the transactions itself: Is it to affect a genuine sale or just compliancy with procedure to be Shariah compliant? Dusuki (2010) also questioned the issue of separate prices for delivered and non-delivered commodities on Bursa Suq Al-Sila (Malaysian commodity market) that if the intention of the sale was never to make the delivery in the first place, it renders the whole transaction to be fictitious and casts doubt to its purity.

Tawarruq has become a quick fix for the Islamic finance industry and will continue to be used widely unless alternative products that could be more effective are introduced to phase it out of the system. As Dusuki (2010, p. 24) puts it, "Islamic financial institutions will continuously appear as practitioners of mere semantics, their functions and operations essentially no different from the conventional space, except in their use of euphemisms to disguise riba and circumvent other Shariah prohibitions". The Islamic finance industry thus requires an examination of the interdependent and complementary effects of the various Islamic contracts.

\section{Application of Tawarruq in modern Islamic finance and banking}

\subsection{Home Financing}

Tawarruq is perhaps one of the most popular modes for house financing in Malaysia. A survey of the product disclosure sheets of the Islamic banks in Malaysia revealed that eight of the sixteen banks offer house financing under the concept of Tawarruq. Figure 6 below shows the modus operandi of Tawarruq based house financing.

Notably, the search for alternative to the use of Tawarruq is largely actuated by the need to avoid issue that raise concern of shariah non-compliance among other risk factors in offering Islamic financial products and services. It is remarkable that the process of Tawarruq may have allowed Islamic banks to seemingly circumvent the restrictions of providing cash finance in the form of an interest-bearing loan to house financing customers. Nonetheless, many scholars criticize this process to be a hilah (trick) to legitimize interest taking. Umar "Abd al-'Aziz stated that Allah (SWT) permits the sale and purchase when the objective of the transaction is trading.

Tawarruq is widely adopted by Islamic financial institutions in Malaysia which raises concerns over mounting personal and corporate debts. The use of Tawarruq also raises accounting concern as the monetary values may not be reflected accurately in the involved parties while the commodity is traded from one party to another (Bacha and Mirakhor, 2013). In the similar vein, the process raises concerns with respect to validity of purpose as a critical requirement of any sale transaction from shariah and economic perspective. The fact that neither the customer nor the bank has any intention to own or possess the commodities but to gain liquidity by buying and selling, defeats the validity of purpose requirement.

International Journal of Management and Applied Research, 2020, Vol. 7, No. 2 
Being built upon the notion of profit and risk sharing, the Islamic financial system is supposed to contribute to the growth and development of real economy. However, a series of simultaneous transactions between the customer and bank conducted in succession in Tawarruq lacks a connection to real economy which undermines this objective. Moreover, the overuse of Tawarruq may not create sustainable value due to the inherent debt nature of the concept of Tawarruq. The high concentration of Tawarruq also creates concentration of credit risk for the banks. The more worrisome concern is perhaps the banks being able to securitize these debts and sell them in order to mitigate risks effectively shifting all risks from the banks. This practice would not lead to sustainable financial practices in the long run. Excessive leveraging and speculation were the root cause of the sub-prime crisis of 2008 and the collapse of many financial institutions.

In Malaysia, since the inception of the first Islamic bank, Bai' Bithaman Ajil (BBA) was the first shariah contract used to structure house financing product. However, the practice of BBA led to the practice of 'inah and since 'inah is a shariah contract which is not accepted by all scholars, the practice of BBA was always under criticism. Apart from the inah factor, BBA is being criticized on the ground of not being Shariah compliant when the bank does not take the risk of ownership and liability of the property and interest rate is still being used (although implicitly) to act as a benchmark in calculating the profit margin and thus, creating a feeling of uneasiness among the Muslim consumers (Razak et al., 2011). In the quest to find an alternative to BBA home financing, Malaysian banks adopted Tawarruq or Commodity Murabahah based home financing among other types such as Musharakah Mutanaqisah (diminishing partnership).

\subsection{Tawarruq in Personal Financing (Credit Card)}

Credit card has become an indispensable part of modern living and it has created a competitive market for banking sector. However, the application of the concept in Islamic finance has been long debated due to the inherent features of credit cards and because it involves the practice of riba (interest). There is a disparity between the contemporary juristic views on the credit card where the view is split between those who deem it permissible subject to fulfilment of certain conditions, and those who consider credit card to be impermissible. The conditions noted by the jurists who allow it are the full settlement of the outstanding balance during the grace period and not allowing cash withdrawals or any action that might trigger the interest clause.

The use of Islamic credit cards in Malaysia started in 1996 with AmBank introducing Al-Taslif credit card under the concept of Bai' Inah. Unlike conventional credit cards, the Islamic credit card must be used strictly for shariah compliant purchase of goods and services. While phasing out Bai' Inah, Tawarruq (deferred payment basis) and ujrah (fee-based transaction basis) are now being used as the underlying contracts for credit card. Again, the use of Tawarruq for credit card has become questionable due to the prohibition of using money to make money. From an economic perspective, with no corresponding economic activity tied to the credit created, the use of this model for credit cards leads to money creation which in turn could lead to increasing inflation.

International Journal of Management and Applied Research, 2020, Vol. 7, No. 2 


\subsection{Islamic Fixed Deposit}

Another controversial financing product fuelled by Tawarruq is the Islamic fixed deposit. Fixed deposits are popular among customers who are more risk averse and prefer fixed returns for their investments. Islamic banks have been able to achieve this and guarantee profit rates to customers by using Tawarruq as the underlying concept for this product.

With the use of the simultaneous purchase and sale transactions of Tawarruq on the commodity market, banks effectively generate profits for the customer instantly. Few Malaysian banks use this opportunity to lure customers by promising upfront profit payment for their fixed deposit investments with the deposit capital deferred till maturity. As with all Tawarruq products, the commodities are traded with no intentions of ownership or possession. Questionably, the same commodities could be the subject of several Tawarruq transactions without moving from the spot. As alluring as it is to customers, the result of the transaction becomes the making of money out of money. The same concerns of the contract of Tawarruq are raised by jurists. The lack of correlation of this transaction to any positive economic activity makes its use questionable as a shariah-compliant product that promotes maqasid al-shariah.

Alternatively, there are other shariah contracts that could be used for fixed deposits that could have positive economic implications.

\section{Alternative Islamic Contracts to Tawaaruq based Financial Products}

Tawarruq component infects the different types of commodity murabaha contracts. Commodity Murabahah is based on tawarruq, which is an arrangement that deals with a purchase of an asset on Musawamah or normal sale, where price is agreed via bargaining or Murabahah and back-to-back a sale of the same asset to a third party takes place to obtain cash (Muneeza et al, 2020). In 2009, Bursa Malaysia introduced Bursa Malaysia Suq Al-Sila', a special exchange trading platform designed to facilitate tawarruq transactions, particularly for Islamic banks using crude palm oil (CPO) as the commodity used. This electronic platform is used by the Islamic banks in Malaysia to do commodity Murabahah trading, and hence this section explores how this happened to the financial product currently offered in the market namely; House financing, Personal financing (credit card) and Islamic fixed deposit using Bai' Salam and Ijarah contracts. The proposed alternatives seek to address issues and concerns raised by Islamic scholars and economists on the procedural aspects and outcomes of using Tawarruq to offer these products. Firstly, an overview of Bai' Salam and Ijarah contracts is presented, which is then followed by a discussion of the usages of these contracts in personal finance, home financing, and fixed deposit.

\subsection{Bai' Salam}

Contract of Salam is defined as a "Sale contract based on order of certain asset with certain specifications. Full payment is made in cash at the time of conclusion of the contract whereas the delivery of the asset is deferred to a specified time" (Bank Negara Malaysia, 2010, p. 216). Unlike Tawarruq that give credit facility to all kinds of goods and services, Salam contract is restricted to manufactured goods and agricultural products only. This naturally leads to a series of problems for Islamic financial

International Journal of Management and Applied Research, 2020, Vol. 7, No. 2 
institutions. When it comes to the commercial application of the contract by Islamic financial institutions, the foremost concern for Islamic financial institutions is the fact that dealing with commodities is both time-consuming and labour-intensive. Such problem can be mitigated through parallel Salam contracts whereby the bank enters into two separate contracts: the first Salam contract with the seller and the second contract with the buyer of the commodity. In so doing, the bank acts as an intermediary between the two parties (Kaleem and Ahmad, 2010). Some Islamic banks have had great success with Salam-based microfinance offerings (Obaidullah, 2015), which suggests that it could be used for other commercial applications too.

\subsection{Ijarah}

The contract of Ijarah is more popular in Islamic finance as it has many similarities with the conventional finance lease and has involved less risk for the bank. The Bank Negara defines Ijarah as "a lease or commission contract that involves an exchange of usufruct or benefits of an asset or a service for rent or commission for an agreed period" (Bank Negara Malaysia, 2010 pp. 3). Duration of the lease period and the rental fees are pre-agreed and contracted between the parties to the contract. Ownership of the asset is retained with the lessor (the bank) and he is responsible for the loss or damage to the asset during the lease period unless due to negligence by the lessee. The contract of Ijarah can end in the lessee (customer) returning the asset to the lessor (bank) or in the full ownership transfer to the lessee or in the lessee purchasing the asset from the lessor depending on the pre-agreed terms of the agreement. There have been juristic concerns regarding the issue of ownership of the asset during the contract period in the commercial use of Ijarah (Dieng, 2019). However, Ijarah could be useful for all stakeholders when used creatively. The following sections discuss possible usage for home financing, credit card, and fixed deposit.

\subsection{Musharakah Mutanaqisah (a hybrid of Musharakah and Ijarah)}

One alternative to house financing is using Musharakah Mutanaqisah (Diminishing Partnership with lease), a hybrid product of Musharakah and Ijarah that is being widely utilized by Islamic financing institutions. In this product both the bank and the customer share the risk of purchasing the asset as it is jointly owned by both parties (Subky, et al., 2017). Musharakah Mutanaqisah is also less controversial and accepted by jurists of all schools. Musharakah Mutanaqisah is offered by Islamic banks across the world, ranging from African, Asian, European, to Middle East countries (Moriguchi, et al., 2016).

This product also offers more flexibility for both parties. The bank is not tied to a fixed rental rate throughout the tenure of the financing period. It could be revisited and revised according to market conditions, unlike the fixed interest rate imposed under Tawarruq contract. This reduces the risks from dynamic markets of price fluctuations in long term financing for the banks. It is also more appealing to the customers as they can claim ownership of the property by redeeming the principle sum of the banks share (Subky, et al., 2017). The increasing partnership of the customer in the property also provides more assurances to the customer. Figure below illustrates modus operandi of this mode of financing.

International Journal of Management and Applied Research, 2020, Vol. 7, No. 2 
Figure 1: Modus Operandi of Musharakah Mutanaqisah financing

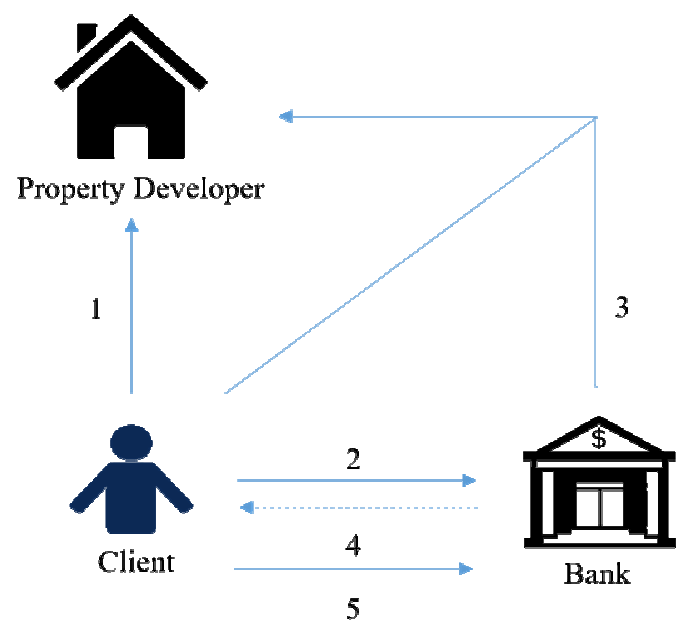

Explanation of Steps:

1. The client identifies the property and executes SPA with property developer.

2. The client approaches bank to obtain MM financing facility.

3. The bank and client enter MM financing facility and purchases the property from the property developer.

4. The bank leases its share of the property to the client.

5. The client pays an amount in addition to the rental in order to buy the banks share of the property. The partnership will be terminated when the client owns $100 \%$ of the property.

However, Musharakah Mutanaqisah is not risk-free. Major risk identified for the banks include is the risk of project abandonment by the property developers and the risk of default by the customer. Islamic banks shield themselves against these risks by including a clause to unconditionally grant the right to the bank to hold the customer accountable for the outstanding capital put up by the bank for the financing facility (Subky, et al., 2017). Exposures to these risks make the banks to be more diligent and prudent in evaluating credit worthiness of customers and the identification of projects to finance. From an economic perspective, the debt obligation created by this financing facility is directly associated with a real asset and the growth of the economy which is in line with the principles of shariah.

\subsection{Salam Credit Card}

Islamic credit cards offered under Salam could be the solution for agriculture and rural financing which have been long under explored by banks. Customer will make deferred deliveries of the commodity which the bank would then enter into an agreement to sell to other merchants in a sale transaction. Extending the financing solutions to production would enable for the growth of the economy and its output. Figure 2 illustrates the modus operandi of Salam credit card.

International Journal of Management and Applied Research, 2020, Vol. 7, No. 2 
Figure 2: Modus Operandi of Salam Credit Card

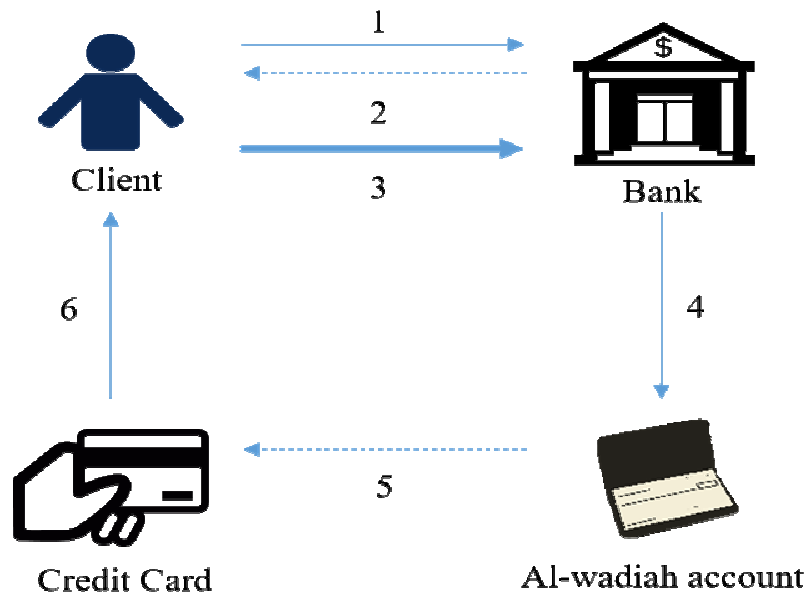

Explanation of Steps:

1. The client requests credit card financing

2. Bank offer purchase price based on credit worthiness evaluation, commodity quality and deferred delivery date

3. The bank and client enter into a Salam agreement

4. The bank disburses the purchase price into the clients wadiah account. Wadiah in Islamic law is a safekeeping contract based on the principle of trust and where the safekeeper does not need to take any liability, except in cases of negligence and misconduct.

5. The purchase price is set as the limit to the credit card

6. Credit card is issued to the client

Personal financing schemes based on Salam are rarely used by banks due to the practical issues involved in its implementation. Offered mostly in the GCC countries, Salam financing has been offered as a retail cash financing product for the day to day cash needs of the bank's customers. In order to overcome concerns regarding the commodity, Dubai banks structured the product with local commodities such as refined sugar that can be easily traded and delivered. To address the issues of sale undertaking, where customers are rarely involved in the trading of commodities, a hiring of a third party as an agent was proposed (GIFR, 2011). Even so, Islamic banks are sceptical regarding the viability of in long run and its ability to compete with Tawarruq based financing.

\subsection{Ijarah credit card}

Ijarah credit card is issued for the purpose of enabling the cardholder to purchase goods and commodities from selected merchants and the repayment is deferred on a 'lease to own' basis. Figure 3 shows the modus operandi of Ijarah credit card.

International Journal of Management and Applied Research, 2020, Vol. 7, No. 2 
Figure 3: Modus Operandi of Ijarah Credit Card

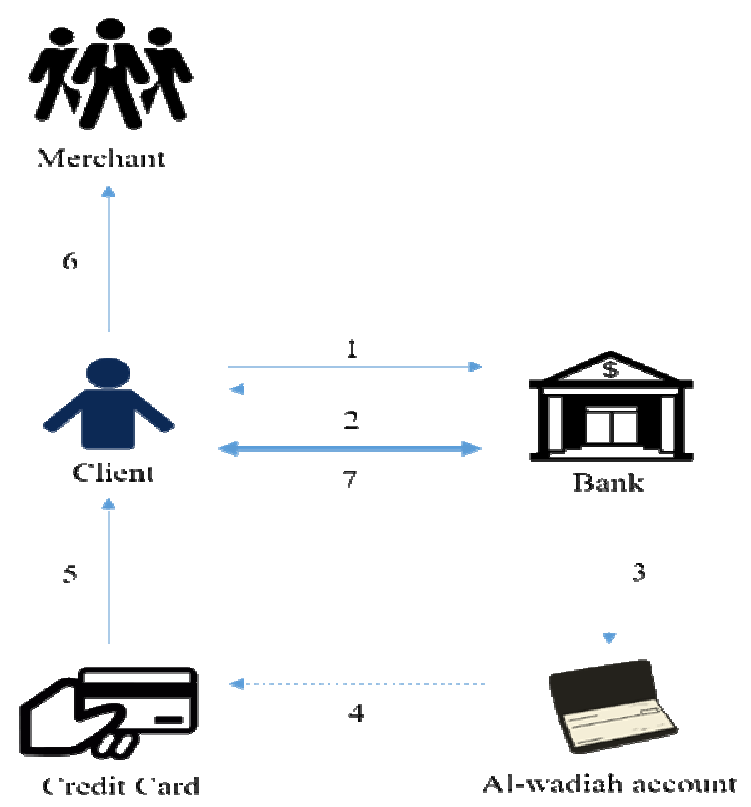

Explanation of Steps:

1. Client requests credit card financing for purchase of a commodity

2. Bank identifies a merchant and appoints client as an agent of the bank

3. The bank disburses the purchase price into the clients wadiah account.

4. The purchase price is set as the limit to the credit card

5. Credit card is issued to the client

6. The client purchases the commodity as an agent of the bank

7. The bank rents the commodity to the client on AITAB concept and pays monthly rentals

Islamic credit card based on the contract of Ijarah is less common than Tawarruq credit card because not all assets can be leased and thus the application of Ijarah credit card is somewhat limited (Kahf and Mohomed, 2016). This card can only be utilized for the purchase of an asset that can be subsequently leased back to the customer for a predetermined rental for an agreed period of time. After the agreed upon rentals have been settled with the bank, ownership of the asset is thus transferred to the customer. The requirements that need to be fulfilled for the asset being leased limit the use of the card. Additionally, the card cannot be also used for cash withdrawals. However, Ijarah credit card can be helpful for financing education and healthcare, which requires through examination.

\subsection{Salam Fixed Deposit}

Applying the contract of Salam to the fixed deposit product is expected to address several issues that have been raised in the application of Tawarruq. In Tawarruq, the commodities are traded in seconds on the commodity platform and the profit is

International Journal of Management and Applied Research, 2020, Vol. 7, No. 2 
generated with no economic implications. On the other hand, in the contract of Salam, the banks would have to invest capital in the production of specified commodities and take physical or constructive delivery of them before selling them to a merchant or another commodity trader for a profit. In doing so, the banks would play a role both the supply and demand of the commodities. From an Islamic finance perspective, this contract fulfils the principles expected in shariah. Figure 4 shows the modus operandi of Salam fixed deposit.

Figure 4: Modus Operandi of Salam Fixed Deposit

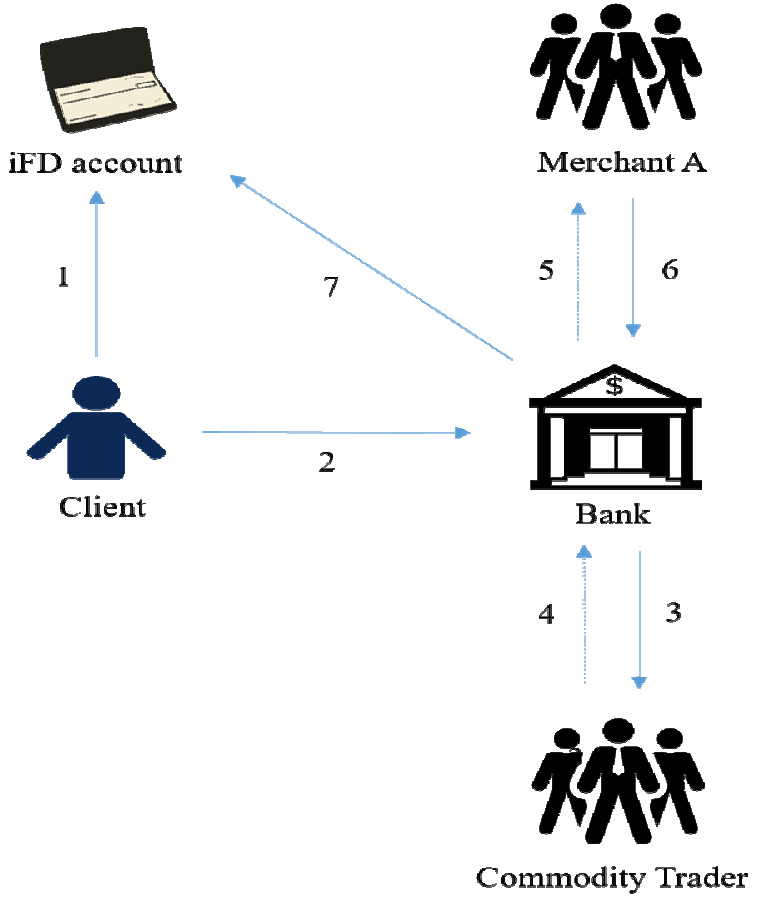

Explanation of Steps:

1. The client deposits money into an Islamic fixed deposit account

2. The client hires the banks as his agent

3. As an agent, the bank enters into a Salam agreement with a commodity trader. Payment is made on the spot in full (discounted price).

4. The commodity trader makes deferred delivery of commodity as agreed

5. As an agent, the bank simultaneously enters into a master sale agreement with a merchant for the purchase of the goods

6. The merchant makes spot payment for deferred delivery

7. The bank deposits the payment into iFD account for customer

Financial institutions however are reluctant to use Salam contract due to its associated risks, including counter party risks, price risks, asset holding risks and low investment return or loss risks (Kaleem and Ahmad, 2010). These risks could be mitigated with proper controls put in place such as purchase of goods from stringent credit evaluated suppliers, purchase goods with marketing potential, combination of the product with

International Journal of Management and Applied Research, 2020, Vol. 7, No. 2 
security contracts such as kafalah and rahn, and penalty clauses within the contract to deter default by the suppliers.

In 2010, Dubai Islamic Bank (DIB) launched a Salam based product for financing needs called "Al Islami Salam Finance". In this structure, the bank buys a commodity from the customer through a Salam contract with spot payment, giving the cash liquidity needed by the customer (Saleem et al., 2014). The customer will then buy the commodity from a broker (a sister company of DIB) and will make delivery at the maturity date. The bank will then sell the commodity and obtain its money back. Saleem et al. (2014, p.186) observes that this structure has a major weakness as there is a market risk in the commodity sold as the bank does not lock in the selling price of the commodity it receives at maturity in advance. Saleem et al (2014) observe that even though the concept of Salam is utilised by Islamic financial institutions, it lacks a best practice model due to two major obstacles. One obstacle is the lack of application of hedging instruments to eliminate the market risk arising from the commodity prices and another obstacle is the current dependence on Commodity Murabahah which is easier to implement with no market risk.

Saleem et al. (2014) proposed reverse Salam as a deposit product as an alternative to Tawarruq based deposits. Reverse Salam basically means that Salam contract as a fixed deposit whereby the seller is the bank (the bank represents the party supplying the commodity in the future) and the buyer is the customer (who provides the cash deposit). This is a liability product of the bank.

\section{Conclusion}

Critics of Islamic finance have long debated that there seems to be little difference with the conventional finance system and the current Islamic finance products does not fulfil the expectations of the core principles that make up the basis of this revolutionary alternative system. In hindsight, when Islamic finance was first introduced into the modern financial system, it lacked the operational framework and a viable structure for commercial banking. Practitioners and scholars therefore had no alternative but to rely on the conventional financial system to create the model for Islamic financial institutions and products replicating the conventional system that were made Shariah compliant. Contrary to popular belief, this method was much needed for the development and promotion of the Islamic finance system. However, given that the Islamic financial system is now not in its early development stages, practitioners must divert from the norms and practices based on replicating from the conventional system and find alternative models that are more in line with the Shariah principles and objectives. This system has to become an agent of positive change to restore the weakening public confidence.

The development of the economy, creation of wealth and its fair distribution are ones of the core ideologies surrounding Islamic finance. The Bank Negara initiative to mould the Islamic finance system into Value Based Intermediation (VBI) is a step forward into achieving this objective. Not limiting to just banking which is shariah compliant but to aim to deliver the intended outcomes of shariah through its practices, conducts and offerings that would help generate positive and sustainable impact to the

International Journal of Management and Applied Research, 2020, Vol. 7, No. 2 
economy, community and environment, that is consistent with the sustainable returns and interests of the shareholders (Bank Negara Malaysia, 2018). This initiative would not just help to attain the intended objectives of shariah but create a more sustainable financial system.

In addition to redefining the system, critical attention needs to be given for assessing the implications on the real economy of the products used in Islamic finance. Satisfaction of just the legal requirements in its technical and operational context to be in line with shariah should not be the sole basis for product development. Analysis on how the product would, create or destroy value for the economy, distribute or hoard wealth and use or exploit resources should be visited and emphasized.

It has been made evident that the products of Tawarruq used for financing by Islamic banks fail to achieve these objectives. The current loopholes in the system allow the underlying assets to be the subject of several transactions with almost no physical delivery or transfer of ownership. The end result of the transaction appears to be that of a conventional loan with riba being disguised and made shariah compliant. It is also revealed that the positive social and economic impact of Tawarruq is next to minimal. Further, heavy dependence of these products makes the Islamic finance system to become more debt based and its proliferation thus negating its pious objectives. This research has examined the use of Salam and Ijarah which are consistent with the Shariah principles, as alternatives to Tawarruq financial products.

Salam has been criticised by practitioners as being complex for commercial application and entails more risk for the financial institutions compared to Tawarruq. Therefore, further research could explore advanced technology, such as blockchain technology, to mitigate potential risks and increase transparency. Additionally, more research could be done on formulating a Salam platform with intermediary financial institutions that unite the supply and demand side for goods.

\section{References}

1. Accounting and Auditing Organization for Islamic Financial Institutions (AAOIFI) (2010), Shariah Standards for Islamic Financial Institutions, Bahrain: AAOIFI.

2. Ahmad, E. F., Shihama, M., Mohamad Tarmizi, N. A., Jibril, S. M., Djama, S. I. and Muneeza, A. (2017), "Tawarruq as a Product for Financing within the Islamic Banking System: A Case Study of Malaysian Islamic Banking System", International Journal of Management and Applied Research, Vol. 4, No. 1, pp. 31-43. https://doi.org/10.18646/2056.41.17-004

3. Ahmed, H. and Aleshaikh, N. (2014), "Debate on Tawarruq: Historical Discourse and Current Rulings", Arab Law Quarterly, Vol. 28, No. 3, pp. 278-294. https://doi.org/10.1163/15730255-12341282

4. Al-Jarhi, M. A (2013), "Gaps in Theory and Practice of Islamic Economics", Journal of King Abdul Aziz University - Islamic Economics, Vol. 26, No. 1, pp. 243-254. https://doi.org/10.4197/Islec.26-1.11

International Journal of Management and Applied Research, 2020, Vol. 7, No. 2 
5. Bacha, O. I. and Mirakhor, A. (2013). Islamic Capital Markets: A Comparative Approach. Singapore: John Wiley \& Sons.

6. Bank Negara Malaysia (2018), Monthly Highlights and Statistics January 2018, Malaysia: Bank Negara, pp-44, available at: http://www.bnm.gov.my/index.php?ch=en_publication\&pg=en_msb\&ac=254\&en $\underline{\text { \&uc }=2}$ (accessed 15 March 2018)

7. Bouheraoua, S. I. (2013), "Tawarruq in the banking system: a critical analytical study of juristic views on the topic", presented in 19th Session OIC Fiqh Academy, United Arab Emirates, available at: https://ifikr.isra.my/library/pub/304 (accessed on 1 April 2018)

8. Dieng, M. M. (2019), “The Applicability of Ijarah Al-Mawsufah Fi Al-Dhimmah in Malaysia", International Journal of Management and Applied Research, Vol. 6, No. 4, pp. 196-207. https://doi.org/10.18646/2056.64.19-014

9. Dusuki, A. W. (2010). "Can Bursa Malaysia's Suq Al-Sila' (Commodity Murabahah House) Resolve the Controversy over Tawarruq?" ISRA Research Paper, No. 10, pp. 1-26.

10. Global Islamic Finance Report (GIFR) (2011), Global Islamic Finance Report, Available at: http://www.gifr.net/gifr_2011.htm (accessed on 23 March 2018).

11. Global Islamic Finance Report (GIFR) (2016), Global Islamic Finance Report, Available at: http://www.gifr.net/gifr 2016.htm (accessed on 23 March 2018).

12. Ibn al-Humam, Fath al-Qadar, Vol. 5, p. 425.

13. Ibn Taymiyyah, Al-Qawa'id al-Nura Niyyah, p. 167.

14. Islamic Financial Services Board (IFSB) (2017), Islamic Financial Services Industry Stability Report 2017, Available at: http://www.islamicfinance.com/wpcontent/uploads/2017/06/IFSB-IFSI-Stability-Report-2017.pdf (accessed on 23 March 2020).

15. Kahf, M. and Mohomed, A. (2016), "Credit Cards: Contemporary Issues from Economic and Shariah Perspective", Journal of King Abdulaziz University: Islamic Economics, Vol. 29, No. 1, pp. 57-80. https://doi.org/10.4197/Islec.29-1.4

16. Kaleem, A, and Ahmad, S (2010), "Bankers' perception towards Bai Salam method for agriculture financing in Pakistan”, Journal of Financial Services Marketing, Vol. 15, No. 3, pp. 215-227. https://doi.org/10.1057/fsm.2010.18

17. Mohamad, N. and Ab Rahman, A. (2014), "Tawarruq application in Islamic banking: a review of the literature", International Journal of Islamic and Middle Eastern Finance and Management, Vol. 7 No. 4, pp. 485-501. https://doi.org/10.1108/IMEFM-10-2013-0106

18. Moriguchi, T.; Khattak, M. A.; Farhan, M.; Firdaus, M.; Worasutr, A.; Hakim, A. L.; Musthafa, F.; Muneeza, A. (2016), "Contemporary Practices of Musharakah in Financial Transactions", International Journal of Management and Applied Research, Vol. 3, No. 2, pp. 65-76. https://doi.org/10.18646/2056.32.16-005

19. Muneeza, A., Fauzi, M.F., Nor, M.F.B.M., Abideen, M. and Ajroudi, M.M., (2020), "House financing: contracts used by Islamic banks for finished properties

International Journal of Management and Applied Research, 2020, Vol. 7, No. 2 
in Malaysia", Journal of Islamic Accounting and Business Research, Vol. 11, No. 1, pp. 168-178. https://doi.org/10.1108/JIABR-04-2017-0057

20. Obaidullah, M. (2015), "Enhancing food security with Islamic microfinance: insights from some recent experiments", Agricultural Finance Review, Vol. 75 No. 2, pp. 142-168. https://doi.org/10.1108/AFR-11-2014-0033

21. Razak, D.A, Fauziah, Talib, M.D. (2011) "Consumers' perception on Islamic home financing: Empirical evidences on Bai Bithaman Ajil (BBA) and diminishing partnership (DP) modes of financing in Malaysia", Journal of Islamic Marketing, Vol. 2, No. 2, pp.165-176. https://doi.org/10.1108/17590831111139875

22. Saleem, M.Y, Mahaini, M.G, Kuresh, H. (2014), "Reverse Salam as an Innovative Instrument for Investment Accounts", ISRA International Journal of Islamic Finance, Vol. 6, No. 1, pp. 182-193. https://doi.org/10.12816/0019258

23. Shahruddin, A (2013), "Is Bay' Al-Tawarruq a better alternative in fulfilling Islamic Finance Objectives", in Aziz, R.A (Ed), Celebrating 30 Years of Islaminc Banking and Finance Institutions in Malaysia 1983-2013, Unit Penerbitan USIM, Bandar Baru Nilai, Malaysia.

24. Siddiqi, M. N (2004), Riba, Bank Interest and the rationale of its prohibition, Jeddah: Islamic Development Bank.

25. Siddiqi, M. N (2007), "Economics of Tawarruq: How the Mafasid overwhelm the Masalih", paper presented at: Tawarruq: A Methodological Issue in ShariahCompliant Finance, 1 Feb 2007, London: London School of Economics, available at: http://www.siddiqi.com/mns/Economics of Tawarruq.pdf (accessed 25 March 2018).

26. Subky, K. H. Liu, J. Y., Abdullah, M. Farhan Mokhtar, Z. and Faizrakhman, A. (2017), "The Implication of Musharakah Mutanaqisah in Malaysian Islamic Banking Arena: A Perspective on Legal Documentation", International Journal of Management and Applied Research, Vol. 4, No. 1, pp. 17-30. https://doi.org/10.18646/2056.41.17-003

International Journal of Management and Applied Research, 2020, Vol. 7, No. 2 